\title{
EMPLOYERS’ POLICIES AND ATTITUDES TOWARDS THE PERFORMANCE OF OLDER EMPLOYEES IN LITHUANIA
}

\author{
Daiva SKUČIENE் ${ }^{1}$, Julija MOSKVINA (1D) 2 \\ ${ }^{1}$ Institute of Sociology and Social Work, Vilnius University, Vilnius, Lithuania \\ ${ }^{2}$ Lithuanian Social Research Centre, Vilnius, Lithuania \\ E-mails: ${ }^{1}$ daiva.skuciene@fsf.vu.lt; ${ }^{2}$ julija.moskvina@dsti.lt (corresponding author)
}

Received 10 June 2019; accepted 04 November 2019

\begin{abstract}
The ageing labour force is the one of the main challenges for the labour market in Lithuania. The working career of older employees very much depends on the policies and attitude of employers. Thus, the aim of this paper is to analyse the policies and attitudes of Lithuanian employers towards older employees. The data of Eurobarometer 76.2 in 2011 and the data of the employers' survey in Lithuania in 2014 were used for the implementation of the goal. The construction, trade, education, health care and public administration sectors were selected on arbitrary basis. The respondents were surveyed by telephone. The sample of the survey included 216 managers or staff managers. The employers in primary data of Eurobarometer 76.2 were defined as general and middle managers. The data were analysed using the method of factor analysis. The secondary Eurostat data were used for the analysis of socioeconomic context. The legal norms were analysed using national documents. The main findings of the research reveal the general positive attitude of employers towards older workers in Lithuania. However, the existing workplace practice gives little encouragement for prolonging the working career in older age due to obsolete cultural and legal norms.
\end{abstract}

Keywords: employers, old age, employees, attitudes, characteristics.

JEL Classification: D91, J14, J26, M54.

\section{Introduction}

European countries are facing an ageing population. This is linked to the extension of working life and adaptability of labour market to the change in the structure of employees by age. Lithuania as other European countries faces ageing population as well as the high emigration. Therefore the lack of labour force is nowadays on the agenda of public discussions. On the other hand, the strategy and discussions how to prolong the working life of older employees are not sufficient. Thus the analysis of the obstacles to continue a career in the old age can provide new insights for policymakers.

Among various issues related to the participation of older employees in the labour market is the employer's attitude and implemented policy. Various studies provided findings of the relation between the decision of the employee to continue work in older age and the policies of the employer towards older workers (Van Dalen et al. 2009, Conen et al. 2012, Karpinska et al. 2013).

The attitudes of employers toward older workers were analysed Skučiene et al. (2015). The contribution of this research is to reveal the most significant points of the employers' attitudes towards older employees as a basis of employers' ageing policy. Above mentioned research was supplemented with data of Eurobarometer allowing comparing attitudes of employers and employees. The following research questions were raised: What the attitudes and policies of the employers towards older employees are observed in Lithuania? Are the attitudes discriminatory or favourable for the older employees? Therefore, the goal of this research is to analyse the policies and attitudes of Lithuanian employers towards older employees. For the implementation of the goal, the following objectives are set: firstly, to analyse prior literature on employers' attitudes towards older workers;

Copyright $\odot 2019$ The Authors. Published by VGTU Press.

This is an Open Access article distributed under the terms of the Creative Commons Attribution License (http://creativecommons.org/licenses/by/4.0/), which permits unrestricted use, distribution, and reproduction in any medium, provided the original author and source are credited.. 
second, to review socioeconomic and legal background in Lithuania; thirdly, to analyse the importance of the policies and attitudes of employers towards older workers and finally, to analyse the attitudes of employers that characterize older employees.

\section{Prior literature}

Different perspectives explain the value of career continuity of older employees. The analysis of the stereotypes is also widespread in the academic literature analysing the attitudes of employers toward older employees. The results from van Dalen et al. (2010) survey on perceptions of employers and employees of older workers' productivity showed that both employers and employees rate the productivity of older workers substantially lower than that of younger workers. They also showed the positive relation between the age of the respondent (that of employers as well as employees) and the perceived productivity of the same age group. However, the authors discovered considerable differences between the attitudes of younger and older workers towards each of the productivity dimensions: older workers were considered to have better social skills and to be more reliable, more accurate, and more committed to their work while younger employees scored much higher on such qualities as new technology skills, mental and physical capacity, willingness to learn, and flexibility.

The connection between the attitudes towards older employees and the age of employers themselves was confirmed by van Dalen and Henkens (2017) in their recent study: the older the managers the more positive attitudes towards older workers they hold. The authors stress the importance of the previous experience with the older workers: increase in the occurrence of problems with older workers tends to depress their assessment of soft and hard skills. They also point that characteristics of the businesses add little explanatory power. Indeed, there are evidences that the size and the sector of the business are related to attitudes towards employee. For example, the age stereotypes are particularly strong in certain industries, such as finance, insurance, retail, and information technology/computing (Posthuma and Campion 2008). In a small and medium size company the view on older workers is relatively more positive. Naegele et al. (2018) explain it by flat hierarchies and close social embeddedness within the respective workforce, the monopoly held by older workers on company-specific knowledge, or the fact that older workers often hold key positions within small companies. Research by McNair et al. (2007) has shown that in small companies, the age of the employee does not matter: older people have more skills, experience at work, are more loyal and more concerned with the client's interests. Employers value older workers in health, social care and transportation. Employers seeking to hire or retain older workers, recognizing the value of their skills, knowledge and productivity in manufacturing or in service sectors are taking measures such as adapting the work environment (e.g. better lighting, larger computer screens), applying the flexible forms of work (e.g. part-time work), changing job roles to meet professional aspirations (e.g. mentoring), providing the reward schemes that do not penalize working retirees (Armstrong-Stassen 2007). While motivating older workers to prolong the career the employer along with the ergonomic and organizational decisions at the workplace may utilize the knowledge about specific work values attributed by baby boomers, $\mathrm{X}$, and $\mathrm{Y}$ generation. The generation of baby boomers that were born between 1946 and 1964 place less importance on status, they value less "being promoted more quickly" than generation X. Prestige work value was more important for younger generations (X and $\mathrm{Y}$ ) than the older generation (Baby Boom). People with age also give greater value for work that is consistent with their morals (Hansen and Leuty 2012).

Taylor and Walker (1998) provided evidences that employment practices of older workers are related to employer's attitudes. For example, recruitment, training and promotion practices were related to the perceived trainability, creativity, cautiousness, physical capabilities of older workers, likelihood of having an accident, and their ability to work with younger workers. And perceived productivity, reliability, ability to adapt to new technology, interest in technological change and flexibility of older workers had no relationship with employment practices. As Van Dalen et al. (2009) claims, general dispositional attitudes towards older workers frame perceptions of the abilities of older workers, and thus influence ageist practices at the workplace. The forms of ageism at the workplace usually manifest in hiring and firing decisions of employers, practices occurring within the workplace (being paid less, being left out of promotions, and being left out of companies' modernisation processes), training, retention, and retirement practices (Furunes and Mykletun 2010, Stypińska and Nikander 2018, Abuladze and Perek-Białas 2018).

Further literature review covers the employers' stereotypical thinking towards older employees, although we are aware of other origins of age discrimination in the workplace such as specific workplace characteristics (organizational structures, management, the role of trade unions or staff associations), and the macro-structural processes and factors on a global scale.

Workplace age stereotypes are beliefs and expectations about workers based on their age (Hamilton and Sherman 1994). Henkens (2005) discerns three dimensions of stereotypes: the biased thinking about the productivity, the reliability and the adaptability of older staff. Dordoni and Argentero (2015) (ref. to studies performed by Posthuma and Campion 2008, Bal et al. 2011) present four fields of age 
stereotypes, such as health, employability, age discrimination, and intention to retire. Although the stereotypes can be both negative and positive, the scholars put more attention to the negative ones. Ng and Feldman (2012) detect six most common negative stereotypes about older workers: less motivated, generally less willing to participate in training and career development, more resistant and less willing to change, less trusting, less healthy, and more vulnerable to work-family imbalance.

Negative stereotyping and ageist behaviour towards older workers may result from a perceived "lack of fit" between the job requirements and the abilities of a worker (Naegele et al. 2018). Negative stereotypes typically are held by employers regarding the productivity and other supply-side characteristics of older workers (slower, resistant to change, less well educated and hostile to technology) (Nilsson 2018). Most stereotypes against older workers are on their lower performance or lower ability to learn, their resistance to change, their shorter tenure and being more costly. The notion about less interest in training is the only empirically supported stereotype (Ng and Feldman 2012).

Most common positive stereotypes about older employees include the following: maturity, experience, responsibility, reliability, stability, loyalty, customer service skills, patience, more positive job attitudes, higher levels of organizational citizenship behaviours, dependability, and organizational commitment (Loretto et al. 2000, Posthuma and Campion 2008, Ng and Feldman 2008, 2010, Bal et al. 2011, Malinen and Johnston 2013). The balance of positive and negative stereotypes towards older workers may depend on the sector of economic activity. A more positive stereotyping is found in the retail and health care sectors, whereas negative stereotypes occur more often in the educational sector, public administration as well as manufacturing (Naegele et al. 2018, ref. to Hess 2013). There are also differences between public and private sectors: negative stereotypes towards older workers are stronger in the public sector compared to the private one (Henkens 2005). HR managers judge workers of similar to them age more positively (Henkens 2005, Lazazzara et al. 2013, Principi et al. 2015).

The employer's attitudes towards older workers are also affected by broader cultural, socioeconomic context and legal norms. Different welfare and cultural norms tend to affect managers' behaviour regarding workplace transitions such as promotions and retirement (Radl 2012). Such social policy rules as maximum recruitment ages and pension schemes, other state policies towards older workers (social and political organisation of labour, retirement, and social assistance) can discourage employment of older people (Taylor and Walker 1998, Stypińska and Nikander 2018). As many advanced economies have government-supported policies directed at older workers, it is very likely that employer's attitudes towards such employees are more positive in such economies (Conen et al. 2012). Also the state of the business cycle within a sector influences the managers' behaviour: for example, older workers are much more likely to be rehired after mandatory retirement when the organization face recruitment problems (Karpinska et al. 2013, Oude Mulders et al. 2016). In cases, when employers encounter problems in recruiting new personnel, they may be more likely to back away from retiring older employees and shift their attention towards accommodation and investment measures.

The changes in the realities of labour market (longer working life, more active participation of older people in the labour market) co-exist with the stereotypes of the previous century and their reflections in the legal acts. The scholars (Mikulionienè and Petkevičienè 2006, Rapolienè 2007) state that cultural and value-based environment in the Lithuanian society is unfavourable for older people, whereas older people themselves internalise negative attitudes of society towards the individuals from this age group. The "three-generation" model of labour law from the industrial period is still applied in Lithuania. The traditional labour market regulation model has remained oriented to demographically young population, where the major part of working population maintains the minority of older people who have reached the retirement age (ref. to Guillemard 2015 cited in Ambrazevičiūte 2018). Thus, statutory retirement age has been understood as a necessary condition for leaving the labour market up to now.

Stereotypical attitudes also lead to legal acts that are, in principle, treated as discriminatory (MačernytėPanomariovienè 2008, Ambrazevičiūtè 2018). The legislation in Lithuania provides for an upper age limit for employment and a maximum age limit for individuals applying for certain posts. Having reached the retirement age, people can be deprived of career opportunities, as they are not entitled to additional guarantees in the case of redundancies and lose the guarantees applicable to unemployed people.

\section{Research methodology}

The two surveys were chosen to implement the aim of the research. First, survey, which was implemented in 2014 in Lithuania and the second the survey of Eurobarometer 76.2 in 2011 (European Commission 2014). The survey of employers was a targeted research and was devoted to the analysis of the attitudes of employers toward older employees. As well as the Eurobarometer 76.2 was special and devoted to the topic of ageing. The microdata of Eurobarometer 76.2 was used in the research.

The construction, trade, education, health care and public administration sectors were selected on arbitrary basis for the survey in Lithuania in 2014. The respondents were surveyed by telephone. The sample of the survey included 216 managers or staff managers. 
The data analysis was divided into three stages seeking to answer the following research questions:

Firstly, the responses to the question what socioeconomic and legal conditions for participation of older employees in the labour market are identified in Lithuania were processed. Secondly, the responses to the question if the attitudes of employers are important for the continuing of working career in older age were studied. The third research question aimed to identify what employers' attitudes towards older employees are observed in Lithuania

The secondary analysis of Eurostat data was applied seeking to provide the answer to the first question.

Seeking to study related legal regulations in Lithuania, the document analysis was implemented. The list of the analysed documents is provided in Appendix (see: The List of Documents).

The factor analysis was applied aiming to identify the employers' attitudes as a possible reason for exiting the labour market. The first factor (the reasons presented by the employers and employees) was compared. The data of Eurobarometer 76.2 (European Commission 2014) were used for the analysis of reasons to stop working.

Finally the attitudes of employers were analysed using factor analysis. The employer refers to general managers and middle managers in the primary data of Eurobarometer 76.2 (European Commission 2014). Only the first factor, as the most important one for characterizing the attitude of employer was considered. As Eurobarometer 76.2 (European Commission 2014) was devoted to the attitudes towards older employees, the present analysis was limited only to that particular group.

The data of survey conducted in Lithuania enables comparison of the responses received from the employers belonging to different age groups. Thus the first factor of the attitudes of employers towards older employees was compared by age groups. Since the characteristics attributed to the older employees by the employers under 55 years were very similar, the attitudes of older employers (55+) towards older age employees compared to those of 26-35 year old age employers were selected for comparison and presentation in the paper.

\section{Socioeconomic context and legal norms}

The population ageing in Lithuanian is related to the possible tension in the national labour market, especially to the decline in working age population. The growing demand for labour force is reflected in the positive general employment indicators of older people: the employment rate and activity rate are higher than the EU average. The female employment rate is traditionally high in Lithuania. The growth of total employed population has occurred mainly due to individuals over 50 years old (see Figure 1).

Between 2010 and 2014 the share of employees aged 50 years and over has increased from $25 \%$ to $30 \%$ in total. Some sectors, such as healthcare and education, are characterised by the large share of older employees ( $50 \%$ or more).

Despite the favourable recent trends in Lithuanian labour market, the potential of older workers is underutilized. The data on involuntary part-time employment suggest that many older workers would choose full participation in labour market if the appropriate policies and workplace practices were available (involuntary part-time employment as percentage of the total part-time employment was $25 \%$ in 2011 and 26\% in 2014 in Lithuania for age group 50+, Eurostat). Older workers have been earning less recently as well. This can be explained by the overrepresentation of older workers in declining sectors (Bouman et al. 2015). The Eurobarmeter 76.2 (European Commission 2014) shows that Lithuanians value the role of the 55+ in employment, but less than their role in politics or in the care of grandchildren. According to a population survey (Skučienè et al. 2015), those working in the public administration and defence, compulsory social security and education sectors were the most likely to be active in labour market when they reached retirement age. However, when analyzing the

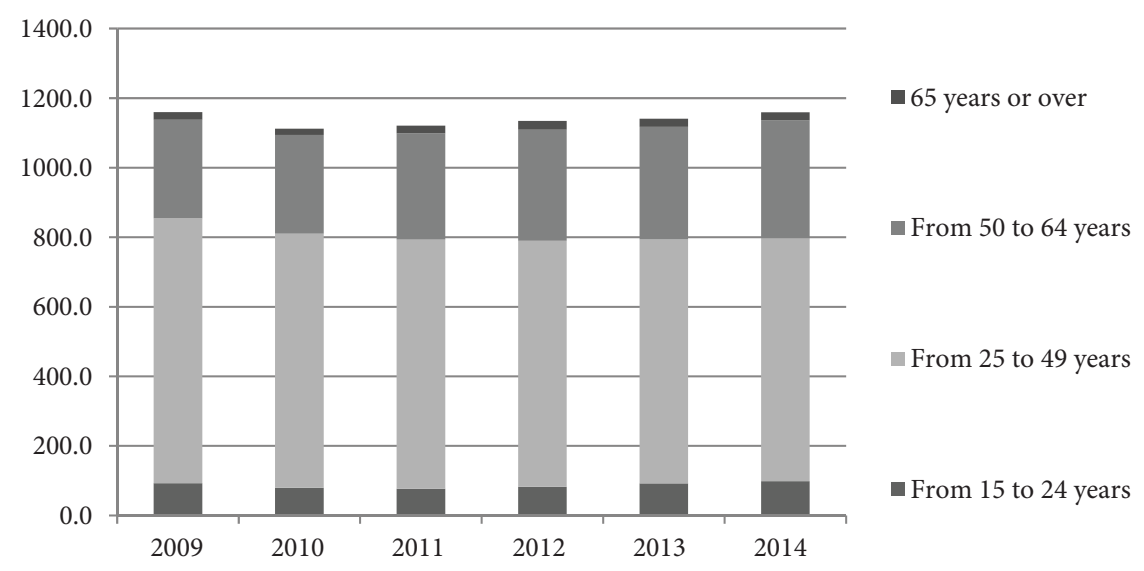

Figure 1. Lithuanian employees by age groups (Eurostat, total, in thousands) 
relationship between retirement age and factors influencing inactivity, greater negative correlation was observed with current employment, professional status, civil servant status, and financial liability.

Older people face the difficulties coming back to the labour market. Following the data of ILO, approximately 30 percent of jobless older workers are unemployed for more than 48 months in Lithuania (Bouman et al. 2015). The proportions of long-term unemployed in the group of women show slower downward tendencies, which confirm the fact that on the average older women face more challenges seeking to regain position in the labour market after a longer break.

Legal norms in Lithuania are strongly related to an upper age limit for employment and a maximum age limit for individuals applying for certain posts in Lithuania. Lower age limits under certain conditions are established applying for a position within intelligence services ( 50 years), 60 years for a position of a notary, for a position in the Special Investigation Service or the Internal Service. The age limit of 62.5 years is set for some positions in the customs and for bailiffs. The age limit that coincides with the official retirement age provided for in the Law on State Social Insurance Pensions ${ }^{1}$ is applied in the service of civil protection. It should be noted that the limit of 62 years and 6 months complies with the established retirement age for men valid by 2012 . Starting with the year of 2012 the legal retirement age has been gradually increasing and will have reached the limit of 65 years both for men and women in 2026.

The applicants for the public service have to be not older than 65 years. The maximum age limit is not applicable to public servants of political confidence and alternate servants. The national normative documents also outline limitations for individuals over 65 years to be elected (appointed) to the posts of heads of the majority of universities or scientific institutions, or to the positions of heads of departments and their deputies. However, such an applicant can be elected or appointed with the approval of the council of scientific institute of university.

It can be concluded that retirement age deprives older people still willing to engage in the labour market of additional guarantees. Having reached the official retirement age, jobless people lose the status of unemployed and are not supported, i.e. not possessing the status of unemployed they cannot actively engage in active labour market policies (e.g. payment of the subsidy is terminated if an individual has reached the old-age pension age). Moreover, the analysis of the practices in the public employment service show that unemployed people of pre-retirement age are more frequently directed to public works and they are never practically offered measures for training or professional development. As provided for in the Labour Code, the individuals

\footnotetext{
1 The established retirement age equals 62 years and 4 months for women and 63 years and 8 months for men in 2018 in Lithuania.
}

of pre-retirement age (who will be entitled to the old-age pension in not more than three years and whose continuous length of service at that workplace is at least ten years) have the right of priority to retain the job in the case of redundancy. However, the employees, who have reached the official retirement age and who have become entitled to the full old age pension working in the employer's enterprise, are deprived of such right.

To sum up, the age norms of the industrial period of the 20th century have existed in Lithuania together with contemporary trends in the labour market: the demand for labour force is increasing, and the older employees are as active in the labour market as ever. However, the national legal documents still provide for maximum age limits for individuals willing to get employed or to extend their working age in some spheres of public sector (including higher education were the requirement of being highly productive is applied). Having reached the retirement age, people can be deprived of their career opportunities, they are not entitled to additional guarantees in the case of redundancies and lose the guarantees applicable to unemployed people. The favourable labour market conditions are not sufficient for wider economic participation of older population due to the obstacles embedded in the legal rules (such as age norms).

\section{Employers' policies towards older workers}

The following reasons for stopping working career were indicated as the most significant ones: exclusion from training, pension/tax system, absence of gradual retirement schemes as well as the view of employers. The latter reason was regarded as similarly important by both employers and employees (see Table 1). Such a finding grounds the importance to clarify the attitudes of employer towards older employees.

The data of the survey performed in Lithuania in 2014 show that more than one third of the employers most frequently referred to "retirement" as a reason for older employees' exit from the labour market. Other significant reasons included health problems of older employees or "too hard work". The provided responses confirm the spread of age norms, when the official retirement age is regarded as a sufficient reason to bid farewell to an employee. They also show that the employers are not ready to take the responsibility for the health-related problems or coping with workload issues of older workers.

The data of survey in Lithuania in 2014 also show that only one fourth of the employers (26\%) pointed out that they encourage their elder staff members (55+) to continue their professional career longer. More than half of the respondents (53\%) do not tend to motivate older employees to extend their professional career and about 17 percent do that partially. The respondents from the health sector more frequently motivate their older personnel to extend their working life compared 
Table 1. The most significant reasons why older employees stop working: the attitudes of employers and employees (source: Eurobarometer 76.2)

\begin{tabular}{|c|c|c|c|}
\hline \multicolumn{2}{|c|}{ Employers } & \multicolumn{2}{|c|}{ Employees } \\
\hline Variables in the factor & Correlation coefficients & Variables in the factor & Correlation coefficients \\
\hline Exclusion from training & 0.771 & View of employers & 0.789 \\
\hline View of employers & 0.764 & Exclusion from training & 0.755 \\
\hline Pension/tax systems & 0.581 & Places not adapted & 0.597 \\
\hline No gradual retirement & 0.515 & - & - \\
\hline $\begin{array}{l}\text { Kaiser-Meyer-Olkin measure of } \\
\text { sampling adequacy. }\end{array}$ & .796 & $\begin{array}{l}\text { Kaiser-Meyer-Olkin measure of } \\
\text { sampling adequacy. }\end{array}$ & .824 \\
\hline \multicolumn{4}{|l|}{ Bartlett's test of sphericity } \\
\hline Approx. Chi-square & 22507122.733 & Approx. Chi-Square & 44103672.492 \\
\hline df & 28 & df & 28 \\
\hline Sig. & .000 & Sig. & .000 \\
\hline
\end{tabular}

to the employers from other analysed sectors. The negative responses (i.e. "do not motivate") are most frequently received from the employers in the trade, construction and public administration sectors. The employers from the enterprises or institutions, where higher education prevailed among personnel, motivated older staff members to extend their working life more often than others.

The employers, who encourage older employees to continue their professional career longer, were requested to elaborate on the applied motivational measures. However, most frequently the employers did not indicate any measures for integration of older employees to the labour market. The obtained responses allow concluding that retention of a job place (its non-abolition) for an elder employee is already regarded as an encouragement to extend his or her professional career. Such measures as combining work and retirement, application of flexible forms of work and life-long learning of employers that are widely spread in foreign enterprises (Conen et al. 2012) are not popular among Lithuanian employers and only subsidised employment is slightly better known.

The employers in the survey in Lithuania indicate that lifelong learning is the most efficient measure of state policy on retaining older people in the labour market. They also express a rather positive attitude towards subsidised employment, anti-discriminatory legal acts and combining work and retirement. According to the employees, the least efficient measures are project initiatives which target at stereotypes. Moreover, the majority of the respondents have never heard of such initiatives. In this regard, the attitude of Lithuanian employers differs from the one shared among employers in the Netherlands, Germany and Poland. The latter consider wage subsidies to be the most efficient measure, and from Italian employers, who appreciate laws preventing age discrimination most (Conen et al. 2012).

Despite the fact that training received the most favourable evaluation from the employers in the survey, they seem not to have any plans for training older employees. The information on vocational education and training (European Centre... 2013) shows that Lithuanian employers provide training for employees less frequently than the EU average, and their financial contribution is lower compared to other member states.

The conclusions of previous research on the influence of economic (labour market) context on employers' decisions (Karpinska et al. 2013, Oude Mulders et al. 2016) have been partially confirmed during this survey. The respondents of the survey were requested to point out measures that they would apply facing staffing challenges. Encouraging the older employees that have reached the retirement age to continue their working life is indicated as the second most popular measure (after pay increase). In addition, more than one third of employers would hire former employees, who are retired, when facing staffing problems.

Referring to retention of older people (from 56 years old to retirement age) in the labour market, the numbers of hired and fired employees in the analysed enterprises significantly differ (Chi-square, $\mathrm{p}-0.00$ ) by the size of enterprise and the status of companies or institutions. Medium and large enterprises of 100 employees and over more frequently dismissed employees from the abovementioned age group taking into account the last 12 months. The ratio of hired and fired employees aged 56+ in the enterprises and institutions with fewer than 100 employees was equal. Business enterprises more frequently employ staff members from the aforesaid age group. Meanwhile, the ratio of employed and dismissed employees in budget and public institutions is significantly less favourable to older individuals.

Such unfavourable policies of budget and public institutions on older personnel are evidenced also at the highest institutional level: in 2018 the Ombudsperson of Equal Opportunities identified factors that violate equal opportunities in the Order of the Minister of Education and Science of RL., i.e. promotion of discrimination against older teachers. 


\section{The employers' attitudes towards older employees}

The employers' stereotypical attitudes may lead to unfavourable organizational behaviour towards older employers. Kunze et al. (2013) indicates that negative attitudes may create prerequisites for spreading ageism at enterprise level what causes the "cascading contextual effect of top management age stereotypes on the discriminatory behaviour of lower levels in the organization". However, our research reveals positive employers' attitudes towards older employees. The main characteristics prescribed to older employees by the employers were very favourable for participation in the labour market (see Table 2). The findings based on Eurobarometer data confirm the results from the research of Loretto et al. (2000), Posthuma and Campion (2008), Ng and Feldman (2008, 2010), Bal et al. (2011), and Malinen and Johnston (2013) who stated that positive stereotypes about older employees include the following: maturity, experience, responsibility, reliability etc.

Table 2. The most significant characteristics prescribed to older employees (55+) from the employer's perspective (source: European Commission 2014 Eurobarometer 76.2)

\begin{tabular}{|l|c|}
\hline \multicolumn{1}{|c|}{ Variables in the factor } & Correlation coefficients \\
\hline Open to new ideas & 0.731 \\
\hline Creativity & 0.719 \\
\hline Up to date & 0.716 \\
\hline Flexibility & 0.688 \\
\hline Productivity & 0.587 \\
\hline Cultural competence & 0.501 \\
\hline $\begin{array}{l}\text { Kaiser-Meyer-Olkin Measure } \\
\text { of Sampling Adequacy. }\end{array}$ & .858 \\
\hline Bartlett's Test of Sphericity & \multicolumn{2}{|c|}{} \\
\hline Approx. Chi-Square & 68857007.936 \\
\hline Df & .000 \\
\hline Sig. & \\
\hline
\end{tabular}

The similar positive characteristics towards older employees can be observed in the data of survey in Lithuania in 2014. The respondents could choose from the list of different characteristics of employees (both positive and negative). All these characteristics, which were indicated by Lithuanian employers are related to experience. The qualities that employers prescribed to younger employees were related more to responsibility and discipline (Table 3). However, the list of main characteristics towards young employees is longer.

Despite the overall positive evaluation, the survey data revealed that employers do not prescribe any characteristics to the employees after the legal retirement age. The contradictory findings about positive view towards older employees in Lithuania and unwillingness to encourage the participation of older employees in labour market
Table 3. The most significant characteristics prescribed to older employees from the perspective of younger (26-35) and older (56 and over) employers (source: The employers survey in Lithuania 2014)

\begin{tabular}{|c|c|c|c|}
\hline \multicolumn{2}{|c|}{56 and over } & \multicolumn{2}{|c|}{$26-35$} \\
\hline $\begin{array}{c}\text { Variables in the } \\
\text { factor }\end{array}$ & $\begin{array}{l}\text { Correlation } \\
\text { coefficients }\end{array}$ & $\begin{array}{l}\text { Variables in } \\
\text { the factor }\end{array}$ & $\begin{array}{l}\text { Correlation } \\
\text { coefficients }\end{array}$ \\
\hline $\begin{array}{l}\text { Ability to master } \\
\text { new information } \\
\text { related to the } \\
\text { specifics of work }\end{array}$ & 0.851 & Responsibility & 0.809 \\
\hline Creativity & 0.791 & $\begin{array}{l}\text { Commitment } \\
\text { to work }\end{array}$ & 0.804 \\
\hline $\begin{array}{l}\text { Mastery of new } \\
\text { technological } \\
\text { (information. } \\
\text { equipment } \\
\text { related. etc.) } \\
\text { knowledge }\end{array}$ & 0.751 & $\begin{array}{l}\text { Loyalty to } \\
\text { workplace }\end{array}$ & 0.762 \\
\hline & & Experience & 0.716 \\
\hline & & Discipline & 0.629 \\
\hline & & Autonomy & 0.591 \\
\hline & & Endurance & 0.590 \\
\hline $\begin{array}{l}\text { Kaiser-Meyer- } \\
\text { Olkin Measure } \\
\text { of Sampling } \\
\text { Adequacy }\end{array}$ & .539 & KMO & .794 \\
\hline $\begin{array}{l}\text { Bartlett's Test of } \\
\text { Sphericity }\end{array}$ & & \multicolumn{2}{|c|}{ Bartlett's Test of Sphericity } \\
\hline $\begin{array}{l}\text { Approx. } \\
\text { Chi-Square }\end{array}$ & 200.918 & $\begin{array}{l}\text { Approx. } \\
\text { Chi-Square }\end{array}$ & 630.636 \\
\hline df & 105 & $\mathrm{df}$ & 105 \\
\hline Sig. & .000 & Sig. & .000 \\
\hline
\end{tabular}

after retirement age could be explained by strict age norms, which are formed by national legal rules.

\section{Conclusions and discussions}

The attitudes of employers towards older workers frame the perceptions of the abilities of older workers and the employment practices in workplace. Usually employers manage their employment practices of older workers based on negative or positive stereotypes. The kind of stereotype depends on the previous experience, economy sector or size of enterprise. The attitudes of employers towards older workers are also influenced by state policy.

Although the Lithuanian labour market is characterised by demand for labour force and an increasing economic participation of older people, they experience obstacles to enter labour market after unemployment span, to access better quality jobs, to improve their productivity through learning. The legal acts still provide age limits applying for certain positions or posts mainly in the public sector; retired jobseekers are not supported in the labour market. 
Our research findings allow us to state that legal norms have strong influence on the employment practice in Lithuania despite the positive attitude that employers hold towards older workers.

The attitudes of employers towards older workers in Lithuania cover the maturity, experience, and creativity and these findings confirm the findings of Loretto et al. (2000), Posthuma and Campion (2008), Ng and Feldman (2008, 2010), Bal et al. (2011), Malinen and Johnston (2013) about common positive stereotypes.

However the research findings reveal that retirement age had strong stereotypical pattern on employers' employment behaviour: the employees of retirement age practically fall out of the employers focus evaluating the characteristics of employees. Other findings also confirm other ageist practices of Lithuanian employers: half of them do not encourage older employees to extend their working life; they do not apply any measures to facilitate older personnel's integration in the labour market; retention of a job place for an older employee is already regarded as an encouragement to extend his or her professional career in itself.

The limitation of research is that the relation between the legal and cultural norms towards older population in the broader or social context was not studied. The impact of the societal norms on employers' behaviour was not analysed either. These aspects may be the focus of further research.

\section{Funding}

The data from the employers' survey 2014 were collected while implementing the research project funded by the Lithuanian Research Council (MIP-080/2013).

\section{Author contributions}

The authors of the paper Daiva Skuciene and Julija Moskvina are both were responsible for the design and development of the research. Daiva Skuciene was more responsible for data analyses and concluding statements. Julija Moskvina wrote the review of prior literature and was more responsible for technical editing. Authors' contribution is 50/50.

\section{Disclosure statement}

Authors declare that they have not any competing financial, professional, or personal interests from other parties. The research project funded by the Lithuanian Research Council (MIP-080/2013) was initiated and managed by Daiva Skuciene.

\section{References}

Abuladze L, and Perek-Białas J (2018) Measures of ageism in the labour market in international social studies. In: Ayalon L, Tesch-Römer C (Eds.) Contemporary perspectives on ageism. Springer, Cham, 461-491.

https://doi.org/10.1007/978-3-319-73820-8_28
Ambrazevičiūte K (2018) Vyresnio amžiaus žmonių teisès ị darbą igyvendinimas visuomenès senèjimo sąlygomis. Daktaro disertacija. Socialiniai mokslai, teise (01 S). Mykolo Romerio universitetas, Vilnius.

Armstrong-Stassen M (2007) Organisational practices and the post-retirement employment experience of older workers. Human Resource Management Journal 18: 36-53. https://doi.org/10.1111/j.1748-8583.2007.00057.x

Bal AC, Reiss AEB, Rudolph CW, Baltes BB (2011) Examining positive and negative perceptions of older workers: A metaanalysis. Journals of Gerontology. Series B: Psychological Sciences and Social Sciences 66: 687-698. https://doi.org/10.1093/geronb/gbr056

Bouman R, Horne R, Milasi S, Prasad N (2015) Ageing and labour market implications for Lithuania. Research Department working paper No. 6. International Labour Office, Research Department. Geneva: ILO.

Conen WS, Henkens K, Schippers J (2012) Employers' attitudes and actions towards the extension of working lives in Europe. International Journal of Manpower 33 (6): 648-665. https:// doi.org/10.1108/01437721211261804

Dordoni P, Argentero P (2015) When age stereotypes are employment barriers: a conceptual analysis and a literature review on older workers stereotypes. Ageing International 40 (4): 393-412. https://doi.org/10.1007/s12126-015-9222-6

European Centre for the Development of Vocational Training (Cedefop) (2013) Lithuania. Country statistical overview http://www.cedefop.europa.eu/EN/Files/3066_en_VetCountryOverview_LT.pdf

European Commission (2014) Eurobarometer 76.2 (2011). TNS Opinion \& Social, Brussels (Producer). GESIS Data Archive, Cologne. ZA5566 Data file Version 2.0.1.

Furunes T, Mykletun RJ (2010) Age discrimination in the workplace: Validation of the Nordic Age Discrimination Scale (NADS). Scandinavian Journal of Psychology 51 (1): 23-30. https://doi.org/10.1111/j.1467-9450.2009.00738.x

Guillemard AM (2015) Age policy. In Smelser NJ and Baltes PB (Eds.) International Encyclopedia of the Social and Behavioral Sciences 1: 267-271. Oxford: Elsevier. https://doi.org/10.1016/B0-08-043076-7/01823-4

Hamilton DL, Sherman JW (1994) Stereotypes (2nd ed.). In: Wyer Jr R, Srull TK (Eds.) Handbook of Social Cognition 2: 1-68. Mahwah, NJ, Lawrence Erlbaum.

Hansen J-IC, Leuty ME (2012) Work values across generations. Journal of Career Assessment 20 (1): 34-52. https://doi.org/10.1177/1069072711417163

Henkens K (2005) Stereotyping older workers and retirement: The managers' point of view. Canadian Journal on Aging/La Revue Canadienne du Vieillissement 24 (4): 353-366. https://doi.org/10.1353/cja.2006.0011

Hess KP (2013) Investigation of nonverbal discrimination against women in simulated initial job interviews. Journal of Applied Social Psychology 43 (3): 544-555. https://doi.org/10.1111/j.1559-1816.2013.01034.x

Karpinska K, Henkens K, Schippers J (2013) Hiring retirees: impact of age norms and stereotypes. Journal of Managerial Psychology 28 (7/8): 886-906. https://doi.org/10.1108/JMP-07-2013-0223

Kunze F, Boehm S, Bruch H (2013) Organizational performance consequences of age diversity: Inspecting the role of 
diversity-friendly HR policies and top managers' negative age stereotypes. Journal of Management Studies 50 (3): 413-442. https://doi.org/10.1111/joms.12016

Lazazzara A, Karpinska K, Henkens K (2013) What factors influence training opportunities for older workers? Three factorial surveys exploring the attitudes of HR professionals. The International Journal of Human Resource Management 24 (11): 2154-2172. https://doi.org/10.1080/09585192.2012.725077

Lietuvos Respublikos civilinès krašto apsaugos tarnybos statuto patvirtinimo ir igyvendinimo ịstatymas. Valstybès žinios, 2003, Nr. 73-3348.469.

Lietuvos Respublikos darbo kodeksas, Valstybès žinios, 201609-19, Nr. 23709.

Lietuvos Respublikos notariato ịstatymas. Lietuvos aidas, 1992, Nr. 192-0.

Lietuvos Respublikos specialiųjų tyrimų tarnybos statuto patvirtinimo įstatymas. Valstybès žinios, 2003, Nr. 38-1656.458.

Lietuvos Respublikos tarnybos Lietuvos Respublikos muitineje statuto patvirtinimo ir igyvendinimo îstatymas. Valstybès žinios, 2000, Nr. 94-2917.

Lietuvos Respublikos teisingumo ministro $2001 \mathrm{~m}$. balandžio 20 d. ísakymas Nr. 73 „Dèl Skyrimo ị vyresniojo teismo antstolio, vyresniojo teismo antstolio pavaduotojo pareigas uždaro konkurso būdu tvarkos bei Teismo antstolių, vyresniųjų teismo antstolių, vyresniųų teismo antstolių pavaduotojų prièmimo i tarnybą konkurso organizavimo tvarkos patvirtinimo“. Valstybės žinios, 2001, Nr. 41-1433.

Lietuvos Respublikos užimtumo įstatymas, Valstybès žinios, 2016-07-05, Nr. 18825.

Lietuvos Respublikos valstybės tarnybos ịstatymas. Valstybès žinios, 1999, Nr. 66.

Lietuvos Respublikos vidaus tarnybos statuto patvirtinimo ìstatymas. Valstybės žinios, 2003, Nr. 42-1927.

Lietuvos Respublikos žvalgybos ịstatymas. Valstybès žinios, 2000, Nr. 64-1931.

Loretto W, Duncan C, White PJ (2000) Ageism and employment: controversies, ambiguities and younger people's perceptions. Ageing and Society 20 (3): 279-302.

https://doi.org/10.1017/S0144686X00007741

Mačernytė-Panomariovienė I (2008) İsidarbinimo amžiaus cenzo nustatymas ir jo pagrịstumas. Teisès problemos 1 (59): 5-23.

Malinen S, Johnston L (2013) Workplace ageism: discovering hidden bias. Experimental Aging Research 39 (4): 445-465. https://doi.org/10.1080/0361073X.2013.808111

McNair S, Flynn M, Dutton N (2007) Employer responses to an ageing workforce: a qualitative study. Department of Work and Pensions, Research Report No 455. 16.

Mikulionienè S, Petkevičienė D (2006) Senatvès įvaizdžiai Lietuvos periodineje spaudoje: tarp pagarbos ir baimès. Socialinis darbas 5 (1): 38-49.

Naegele L, De Tavernier W, Hess M (2018) Work environment and the origin of ageism. In: Ayalon L Tesch-Römer C (Eds.) Contemporary perspectives on ageism. Springer, Cham, 7390. https://doi.org/10.1007/978-3-319-73820-8_5

Ng TW, Feldman DC (2012) Evaluating six common stereotypes about older workers with meta-analytical data. Personnel psychology 65 (4): 821-858. https://doi.org/10.1111/peps.12003
Ng TW, Feldman DC (2008) The relationship of age to ten dimensions of job performance. Journal of Applied Psychology 93 (2): 392. https://doi.org/10.1037/0021-9010.93.2.392

Ng TW, Feldman DC (2010) The relationships of age with job attitudes: A meta-analysis. Personnel Psychology 63 (3): 677-718. https://doi.org/10.1111/j.1744-6570.2010.01184.x

Nilsson K (2018) Managers' attitudes to their older employees: A cross-sectional study. Work 59 (1): 49-58. https://doi.org/10.3233/WOR-172663

Oude Mulders J, Henkens K, Schippers J (2016) European top managers' age-related workplace norms and their organizations' recruitment and retention practices regarding older workers. The Gerontologist 57 (5): 857-866.

https://doi.org/10.1093/geront/gnw076

Posthuma RA, Campion MA (2008) Age stereotypes at the workplace: common stereotypes, moderators, and future research directions. Journal of Management 35: 158-188. https://doi.org/10.1177/0149206308318617

Principi A, Fabbietti P, Lamura G (2015) Perceived qualities of older workers and age management in companies: does the age of HR managers matter? Personnel Review 44 (5): 801820. https://doi.org/10.1108/PR-09-2013-0158

Radl J (2012) Too old to work, or too young to retire? The pervasiveness of age norms in Western Europe. Work, Employment and Society 26 (5): 755-771.

https://doi.org/10.1177/0950017012451644

Rapolienė G (2007) Lietuvos pagyvenusių žmonių identitetas iš postmodernizmo perspektyvos. Gerontologija 8 (2): 109-116.

Skučienė D, Bartkus A, Moskvina J, Uleckiene A (2015) Senejjanti visuomenè: kaip mes pasirengę? Monografija. Lietuvos socialinių tyrimų centras. Vilnius, 2015, 332 p.

Stypińska J, Nikander P (2018) Ageism and age discrimination in the labour market: A macrostructural perspective. In: Ayalon L, Tesch-Römer C (Eds.) Contemporary perspectives on ageism. Springer, Cham, 91-108. https://doi.org/10.1007/978-3-319-73820-8_6

Taylor P, Walker A (1998) Employers and older workers: attitudes and employment practices. Ageing \& Society 18 (6): 641-658. https://doi.org/10.1017/S0144686X98007119

Van Dalen HP, Henkens K, Schippers J (2009) Dealing with older workers in Europe: a comparative survey of employers' attitudes and actions. Journal of European Social Policy 19 (1): 47-60. https://doi.org/10.1177/0958928708098523

Van Dalen HP, Henkens K, Wang M (2014) Recharging or retiring older workers? Uncovering the age-based strategies of European employers. The Gerontologist 55 (5): 814-824. https://doi.org/10.1093/geront/gnu048

Van Dalen HP, Henkens K (2017) Do stereotypes about older workers change? Evidence from a panel study among employers. CentER Discussion Paper, Vol. 2017-028. Tilburg: CentER, Center for Economic Research. https://doi.org/10.2139/ssrn.3005980

Van Dalen HP, Henkens K, Schippers J (2010) Productivity of older workers: Perceptions of employers and employees. Population and Development Review 36 (2): 309-330. https://doi.org/10.1111/j.1728-4457.2010.00331.x 